\title{
A Study on Factors Influencing the Adoption of Internet Banking - A Gender Wise Analysis by Integrating TAM and TPB Model in Kerala
}

\author{
*Athira V S \\ Assistant Professor, Nirmala College, Muvattupuzha, Ernakulam, Kerala
}

\begin{abstract}
The marvelous kinds of innovation in technology and hard-line blend of it with information technology made a paradigm shift in the banking industry. The emergence of Information Technology and its use in the financial sector leads to transition from the brick and mortar structure to click and order model. Information technology developments in the banking sector have sped up communication and transactions for clients. Internet banking is one of the fastest growing banking practices nowadays especially in this pandemic scenario. It is vital to extend this banking feature to clients for maximizing the advantages for both clients and service providers. IB become an inevitable part of the life of customer to do their trans-actions conveniently at any time without visiting the branch. So, it is important to study the various factors with respect to IB usage in Kerala. The present study titled "A Study on Factors Influencing the Adoption of Internet Banking - A Gender wise analysis by Integrating TAM and TPB Model in Kerala" reveals that there are various factors that influence the adoption of internet banking. The study also deals with the gender wise difference in adoption of internet banking and the influence of various factors of adoption.
\end{abstract}

Keywords: Internet Banking, Adoption of Internet Banking, Technology Acceptance Model, Theory of Planned Behaviour, Perceived Ease of Use, Perceived usefulness, Perceived Risk

\section{Article Publication}

Published Online: 12-Nov-2021

*Author's Correspondence

8 Athira V S

8 Assistant Professor, Nirmala College, Muvattupuzha, Ernakulam, Kerala

$\triangle$ athiramails@yahoo.com

$\underline{10.31305 / \text { rrijm.2021.v06.i11.004 }}$

(C) 2021The Authors. Published by RESEARCH REVIEW International Journal of Multidisciplinary. This is an open access article under the CC BY-

NC-ND license

(https://creativecommons.org/licenses/ by-nc-nd/4.0/)

\section{Introduction}

Internet banking is the term used for new age banking system. Banking is a highly information intensive activity that relies heavily on information technology (IT) to acquire, process, and deliver the information to all relevant customers. Banks used the Internet technology as a strategic weapon to revolutionize the way they operate, deliver, and compete against each other. As a result, Internet Banking was introduced as a channel where bank customers could perform their financial transactions electronically via their banks' Web sites. Internet banking is a result of explored possibility to use internet application in one of the various domains of commerce. The challenging business process in the financial services pressurized banks to introduce alternate delivery channel to attract customers and to improve customers' perception.

Customer satisfaction and customer retention are increasingly developing into key success factors in e-banking. Customers have started perceiving the services of bank through internet as a prime attractive feature than any other prime product features of the bank. Customers have started evaluating the banks based on the convenience and comforts it provides to them. Bankers have started developing various product features and services using internet applications based on the perception of customers. Technology Acceptance Model (TAM) is the widely used model in describing the user acceptance of new technology. One of the most utilized models in studying information system acceptance is the technology acceptance model (TAM) in which system use (actual behavior) is determined by perceived usefulness (PU) and perceived ease of use (PEOU) relating to the attitude toward use that relates to intention and finally to behavior. Before accepting Internet banking services, users should be aware 
about benefits, security issues and the risk associated with it, which are important. In this regard, Theory of planned behavior (TPB) with the addition of two extra variables (Subjective Norm and Perceived Behavioral Control) to the model to provide a more comprehensive theoretical perspective of user technology acceptance in the context of Internet banking. So, this study includes TAM and TPB variables along with Trust and Perceived risk which are important in determining customer adoption.

\section{Statement of the Problem}

Banking is not banking was. There has been a paradigm shift in banking owing to multiple delivery channels. The application of most modern technology in banking has completely altered the landscape of banking. Move from brick and mortar to click and portal banking enabled banks to deliver high value-added services at the doorsteps of customers. ATM, internet banking and mobile banking are the major self-service banking technology.

The Customer Adoption of banking technology depends on multiple factors as found in existing literature. There are a no.of theories that describe the adoption of technology. The present study covers various constructs by integrating Technology Acceptance Models (TAM) and Theory of Planned Behaviour (TPB) for describing the customer adoption of Internet Banking and also looks into the gender wise difference in adoption of IB as there is gender disparity in internet banking usage in India.

\section{Significance of the Study}

The study on the customer adoption of Internet Banking is of great importance in the present-day situation. In this pandemic scenario, customers are moving to interact digitally with their banks. Experts says that COVID 19 has put a spot light on the digital banking experience. IB become an inevitable part of the life of customer and also the banks find it easier to increase their operating profits, unlock a new source of value and increased operational efficiency. Today understanding the needs, wants and problems of customers and redefining business operations for satisfying customer's needs are the major challenge facing by banks as the technology is growing very fast and the increased completion in quality of services provided by different banks. According to the World Retail Banking Report 2020, around 57\% of consumers preferring Internet Banking now up from $49 \%$ in the PreCovid 19 period. So it is important to study the various factors with respect to IB usage. Therefore, the present study titled "A Study on Factors Influencing the Adoption of Internet Banking - A Gender wise analysis by Integrating TAM and TPB Model in Kerala" proposes to analyze the various factors that determine the customer adoption of Internet Banking in Kerala by integrating technology adoption theory TAM and TPB along with trust and perceived risk associated with Internet Banking.

With a look on the demographic factors of IB adoption, the gender disparity in internet banking usage in India is a relevant aspect. The reports in 2019 indicates that, the female internet users in India is only half of the male users and the bias is more evident in the rural India. In case of states like Kerala, Tamil Nadu and Delhi the split of male female users is 60:40. Therefore the study also looks into the gender wise difference in adoption of IB.

\section{Objectives}

The study is conducted with the following objectives;

- To identify and study the variations in various factors of adoption between male and female.

- To study the interrelationship between adoption of internet banking and various factors of adoption.

\section{Methodology and Tools of Analysis}

The integration of TAM and TPB as a research framework is used to examine the consumers' intentions towards, and acceptance of, Internet Banking. The study includes 7 constructs such as, Perceived Usefulness, Perceived Ease of Use, Perceived Behavioural Control, Attitude, Perceived Risk and Trust as independent variables and Customer Adoption as the dependent variable. The study will test the strength of the hypothesized relationship of various factors of adoption and internet banking adoption between male and female. 
To establish relationship and association between variables used in the study, explanatory research was used. Survey method using a structured questionnaire was used for collecting primary data from the respondents and secondary data collected from published sources such as records and reports of RBI, reports of banks and other international journals are also used. Structured questionnaire prepared by using several statements to measure the variables identified from literature. The study covers the customers using Internet Banking for doing their banking transactions. The sample size is decided as 100 i.e. data is collected from 100 respondents by using structured questionnaire. Convenience sampling is used for drawing sample from the population. The collected data are analyzed by using appropriate statistical and mathematical tools. Percentages, Mean Deviation, Standard Deviation, t- test, ANNOVA, Correlation and Multiple regression are used for analysis.

\section{Internet Banking- Adoption}

Internet banking is one of the important innovations in the series of technological wonders of the recent past. Internet banking refers to systems that enable bank customers to get access to their accounts and general information on bank products and services through the use of bank's website, without the intervention or inconvenience of sending letters, faxes, original signatures and telephone confirmations.

With the rapid growth of Internet technology, online banking has played an important and central role in the epayment area which provides an online transaction platform to support many e-commerce applications. In the past two decades several theories have emerged that offer new insights into acceptance of information technology. Among these theories, the technology acceptance model (TAM) and TPB has received more attention. The present study analyse the influence of TAM and TPB variables on the adoption of internet banking. TAM model hypothesizes that system use is directly determined by behavioural intention to use, which is in turn influenced by users' attitudes toward using the system and the perceived usefulness of the system. Attitudes and perceived usefulness are also affected by perceived ease of use. Perceived usefulness, reflecting a person's salient belief in the use of the technology and Perceived ease of use is a person's salient belief that using the technology will be free of effort. According to TPB, a person's actual behaviour in performing certain actions is directly influenced by his or her behavioural intention and, in turn, is jointly determined by his or her attitude, subjective norms and perceived behavioural controls toward performing the behaviour. Attitude is defined as "a person's general feeling of favourableness or unfavourableness for that behaviour". Perceived behavioural control (PBC) reflects a person's perception of the ease or difficulty of implementing the behaviour in question. It concerns beliefs about the presence of control factors that may facilitate or hinder their performing the behaviour. Perceived Risk implies the degree of uncertainty inherent in innovations, and therefore they always entail at least some degree of perceived risk.

According to Mayer, Davis and Schoorman (1995) "Trust is the willingness of a party to be vulnerable to the actions of another party based on the expectation that the other will perform a particular action important to the trustor, irrespective of the ability to monitor or control that other party".

\section{Research Hypothesis}

H01 - There is no significant difference in various factors of adoption between male and female.

H0 2 - Adoption variables have no influence on the customer adoption of Internet Banking.

\section{Limitations of the Study}

1. Due to lack of time, the study is confined to Kerala only.

2. The sample size is limited to 100 .

3. The study suffers from all the inherent limitations of the primary data. 


\section{Analysis of Data}

\section{Measures of Adoption of Internet Banking - Gender Wise Analysis}

The usefulness and easiness of internet banking services provided by banks across different sectors may be different and at the same time the attitude or perception of customers towards internet banking may also different. The attitude and behavior of male and female are different. The various factors of adoption are analysed among male and female.

Table-1

Measures of adoption- gender wise analysis

\begin{tabular}{|c|c|c|c|l|l|}
\hline Measures of adoption & Gender & $\mathrm{N}$ & Mean & Std.Deviation & Std.Error Mean \\
\hline \multirow{2}{*}{ PU } & $\mathrm{M}$ & 54 & 27.7778 & 2.64694 & 0.3602 \\
\cline { 2 - 7 } & $\mathrm{F}$ & 46 & $\mathbf{2 8 . 5 6 5 2}$ & $\mathbf{1 . 8 8 1 5 1}$ & 0.27741 \\
\hline \multirow{2}{*}{ PEOU } & $\mathrm{M}$ & 54 & 21.8519 & 2.96143 & 0.403 \\
\cline { 2 - 7 } & $\mathrm{F}$ & 46 & $\mathbf{2 2 . 4 3 4 8}$ & $\mathbf{2 . 1 2 5 5 3}$ & 0.31339 \\
\hline \multirow{2}{*}{ PBC } & $\mathrm{M}$ & 54 & 17.3704 & 2.12173 & 0.28873 \\
\cline { 2 - 7 } & $\mathrm{F}$ & 46 & $\mathbf{1 8 . 0 6 5 2}$ & $\mathbf{1 . 8 3 0 6 3}$ & 0.26991 \\
\hline \multirow{2}{*}{ Attitude } & $\mathrm{M}$ & 54 & 24.9259 & 2.5317 & 0.34452 \\
\cline { 2 - 6 } & $\mathrm{F}$ & 46 & $\mathbf{2 5 . 8 4 7 8}$ & $\mathbf{3 . 1 6 9 0 7}$ & 0.46725 \\
\hline \multirow{2}{*}{ Trust } & $\mathrm{M}$ & 54 & 23.2222 & 2.79937 & 0.38095 \\
\cline { 2 - 6 } & $\mathrm{F}$ & 46 & $\mathbf{2 4 . 4 7 8 3}$ & $\mathbf{3 . 2 5 7 4}$ & 0.48028 \\
\hline \multirow{2}{*}{ PR } & $\mathrm{M}$ & 54 & $\mathbf{2 3 . 6 4 8 1}$ & $\mathbf{6 . 0 5 6 8 3}$ & 0.82423 \\
\cline { 2 - 6 } & F & 46 & 21.3261 & 8.17599 & 1.20548 \\
\hline
\end{tabular}

The table shows variations in measures of adoption among male and female. Considering the table, with regard to usefulness, mean and standard deviation of male are 27.77 and 2.64 compared to 28.56 and 1.88 in case of female. The mean difference is tested by independent sample test, the results shows that the significant value .019 is less than $.05(.016<.05)$ at $5 \%$ level of significance. Therefore, there is significant difference with regard to usefulness between male and female.

With regard to easiness factor, mean and standard deviation of male are 21.85 and 2.96 compared to 22.43 and 2.12 in case of female. The test results shows that the significance value 0.042 is less than $.05(.042<.05)$. Therefore, there is significant difference with regard to easiness between male and female.

With regard to perceived behavioural control, mean and standard deviation of male are 17.37 and 2.12 compared to 18.06 and 1.83 in case of female. The test results shows that the significance value 0.196 is more than .05 (.196>.05). Therefore, there is no significant difference with regard to perceived behavioural control between male and female.

Table-2

Independent Sample Test

\begin{tabular}{|c|c|c|c|c|c|}
\hline \multirow{2}{*}{$\begin{array}{l}\text { Measures of } \\
\text { adoption }\end{array}$} & \multicolumn{2}{|c|}{$\begin{array}{c}\text { Levene's Test for Equality } \\
\text { of Variances }\end{array}$} & \multicolumn{3}{|c|}{ t-test for Equality of Means } \\
\hline & $\mathbf{F}$ & Sig. & Sig. (2-tailed) & Mean Difference & Std. Error Difference \\
\hline \multirow{2}{*}{ PU } & 5.648 & .019 & .095 & -.78744 & .46689 \\
\hline & & & .087 & -.78744 & .45465 \\
\hline \multirow{2}{*}{ PEOU } & 4.230 & .042 & .269 & -.58293 & .52389 \\
\hline & & & .256 & -.58293 & .51051 \\
\hline \multirow{2}{*}{ PBC } & 1.696 & .196 & .085 & -.69485 & .39995 \\
\hline & & & .082 & -.69485 & .39524 \\
\hline \multirow{2}{*}{ Attitude } & 6.836 & .010 & .109 & -.92190 & .57026 \\
\hline & & & .116 & -.92190 & .58053 \\
\hline
\end{tabular}




\begin{tabular}{|c|r|r|r|r|r|}
\hline \multirow{2}{*}{ Trust } & 1.174 & .281 & .041 & -1.2560 & .60561 \\
\cline { 2 - 6 } & & & .043 & -1.2560 & .61301 \\
\hline \multirow{2}{*}{ PR } & 9.214 & .003 & .107 & 2.3220 & 1.42633 \\
\cline { 2 - 6 } & & & .116 & 2.3220 & 1.46032 \\
\hline
\end{tabular}

Source: primary data

With regard to attitude, mean and standard deviation of male are 24.92 and 2.53 compared to 25.84 and 3.16 in case of female. The test results shows that the significance value 0.010 is less than $.05(.010<.05)$. Therefore, there is significant difference with regard to attitude between male and female.

With regard to trust, mean and standard deviation of male are 23.22 and 2.79 compared to 24.47 and 3.25 in case of female. The test results shows that the significance value 0.281 is more than .05 (.281>.05). Therefore, there is no significant difference with regard to trust between male and female.

With regard to perceived risk, mean and standard deviation of male are 23.64 and 6.05 compared to 21.32 and 8.17 in case of female. The test results shows that the significance value 0.003 is less than $.05(.003<.05)$. Therefore, there is significant difference with regard to perceived risk between male and female.

The variations in customer adoption between male and female are analyzed and the results are as follows:

Table-3

Customer Adoption - Gender wise

\begin{tabular}{|l|c|c|c|r|r|}
\hline Measures of adoption & Gender & N & Mean & Std.Deviation & Std.Error Mean \\
\hline \multirow{2}{*}{ Customer Adoption } & M & 54 & 22.4815 & 3.44630 & .46898 \\
\cline { 2 - 6 } & F & 46 & $\mathbf{2 2 . 5 2 1 7}$ & $\mathbf{3 . 9 7 6 2 6}$ & .58627 \\
\hline
\end{tabular}

Source: primary data

Comparative analysis of customer adoption between male and female based on mean and standard deviation shows that, female have highest mean (22.52) than male (22.48).

Table-4

Independent Sample Test

\begin{tabular}{|l|l|l|l|l|l|}
\hline \multirow{2}{*}{ Customer Adoption } & \multicolumn{2}{|c|}{$\begin{array}{c}\text { Levene's Test for Equality of } \\
\text { Variances }\end{array}$} & \multicolumn{4}{c|}{ t-test for Equality of Means } \\
\cline { 2 - 6 } & F & Sig. & Sig. (2-tailed) & Mean Difference & Std. Error Difference \\
\hline \multirow{2}{*}{ Customer Adoption } & 1.648 & .202 & .957 & -.04026 & .74220 \\
\cline { 2 - 6 } & & & .957 & -.04026 & .75077 \\
\hline
\end{tabular}

Source: primary data

The mean difference between male and female with regard to customer adoption is analysed by independent sample $t$ test and the result shows that, the significance value .202 is more than $0.05(.202>0.05)$. Therefore, there is no significant difference between customer adoption among male and female.

Table- 5

Overall analysis of Measures of Adoption

\begin{tabular}{|l|l|l|l|l|l|}
\hline Measures of adoption & N & Min. & Max. & Total mean/item mean & Std. Deviation \\
\hline PU & 100 & 21 & 30 & $28.14(4.69)$ & 2.34 \\
\hline PEOU & 100 & 14 & 25 & $22.12(4.42)$ & 2.61 \\
\hline PBC & 100 & 13 & 20 & $17.69(4.42)$ & 2.01 \\
\hline Attitude & 100 & 20 & 30 & $25.35(4.22)$ & 2.86 \\
\hline Trust & 100 & 16 & 30 & $23.80(3.96)$ & 3.06 \\
\hline PR & 100 & 6 & 30 & $22.58(3.76)$ & 7.16 \\
\hline
\end{tabular}


The table shows that, the highest item mean (4.69) in case of perceived usefulness indicates that respondents are more satisfied with perceived usefulness. The mean score (4.42) is also high in the case of both ease of use and behavioural control. So in general, usefulness is the major factor influencing the respondents to adopt internet banking.

\section{Multiple Regression Analysis}

In multiple regression analysis, interrelationship between a set of variables are established. Hypothesised relationship between one dependent and a set of independent variables are analysed by using advance statistical technique called multiple regression used for predicting the influence of some independent variable on dependent variable. The present study analyse the relationship between internet banking adoption (dependent variable) and various factors of adoption (independent variable) such as perceived usefulness, perceived ease of use, perceived behavioural control, attitude, trust and perceived risk.

\section{$\mathrm{Y}=\mathrm{a}+\mathrm{b} 1 \times 1+\mathrm{b} 2 \times 2+\mathrm{b} 3 \times 3+\mathrm{b} 4 \times 4+\mathrm{b} 5 \times 5+\mathrm{b} 6 \times 6$}

Where, $\mathrm{Y}=$ Customer Adoption

$\mathrm{a}=$ constant (intercept)

$\mathrm{b} 1=$ co efficient of $\mathrm{x} 1$

$\mathrm{x} 1=$ perceived usefulness

$\mathrm{b} 2=$ co efficient of $\mathrm{x} 2$

$\mathrm{x} 2=$ perceived ease of use

$\mathrm{b} 3=$ co efficient of $\mathrm{x} 3$

$\mathrm{x} 3=$ perceived behavioural control

$\mathrm{b} 4=$ co efficient of $\mathrm{x} 4$

$\mathrm{x} 4=$ attitude

$\mathrm{b} 5=$ co efficient of $\mathrm{x} 5$

$\mathrm{x} 5=$ trust

$\mathrm{b} 6=$ co efficient of $\mathrm{x} 6$

$\mathrm{x} 6=$ perceived risk

Table-6

Correlation

\begin{tabular}{|c|c|c|}
\hline \multirow{2}{*}{ Measures of adoption } & Customer Adoption \\
\cline { 2 - 3 } & Pearson Correlation & Sig. (1-tailed) \\
\hline PU & .147 & .072 \\
\hline PEOU & .149 & .069 \\
\hline PBC & $.194^{*}$ & .026 \\
\hline Attitude & $.267^{* *}$ & .004 \\
\hline Trust & $.589^{* *}$ & $\mathbf{. 0 0 0}$ \\
\hline PR & $\mathbf{- . 6 5 1 * *}$ & $\mathbf{. 0 0 0}$ \\
\hline \multicolumn{3}{|c|}{ Source: primary data } \\
$* *$ Correlation is significant at the 0.01 level (1 tailed). \\
$*$ Correlation is significant at the 0.05 level (1 tailed).
\end{tabular}

The strength of the model as indicated by $\mathrm{R}$ square is depicted in the following table:

Table-7

Model Summary

\begin{tabular}{|l|l|l|l|l|l|}
\hline Model & $\mathrm{R}$ & R Square & Adjusted R Square & Std. Error of the Estimate & Durbin-Watson \\
\hline 1 & $.651^{\mathrm{a}}$ & $\mathbf{. 4 2 3}$ & .417 & 2.80939 & \multirow{2}{*}{2.013} \\
\hline 2 & $.710^{\mathrm{b}}$ & $\mathbf{. 5 0 4}$ & .494 & 2.61845 & 2.013 \\
\hline
\end{tabular}

Source: primary data 

a. Predictors: (Constant), Perceived Risk Total
b. Predictors: (Constant), Perceived Risk Total, Trust Total
c. Dependent Variable: Customer Adoption Total

The first model gives an $\mathrm{R}$ square value of 0.423 which states that, $42 \%$ of the variation in customer adoption is predicted by perceived risk alone. In the second model, the $\mathrm{R}$ square value is improved to 0.504 , which states that perceived risk and trust together explains $50 \%$ variation in customer adoption.

Table-8

ANOVA

\begin{tabular}{|c|c|c|}
\hline Model & F & Sig. \\
\hline 1 & 71.904 & $\mathbf{. 0 0 0}^{\mathbf{b}}$ \\
\hline 2 & 49.294 & $\mathbf{. 0 0 0}^{\mathbf{c}}$ \\
\hline
\end{tabular}

Source: primary data

a. Dependent Variable: Customer Adoption Total

b. Predictors: (Constant), Perceived Risk Total

c. Predictors: (Constant), Perceived Risk Total, Trust Total

The table shows that, both the models are statistically significant at $5 \%$ level of significance $(\operatorname{sig}(0.000)<0.05)$.

Table-9

Coefficients

\begin{tabular}{|c|c|c|c|c|c|}
\hline \multirow{2}{*}{ Model } & \multicolumn{2}{|c|}{ Unstandardized Coefficients } & \multirow{2}{*}{$\frac{\text { Standardized Coefficients }}{\text { Beta }}$} & \multirow{2}{*}{$\mathrm{t}$} & \multirow{2}{*}{ Sig. } \\
\hline & $\mathbf{B}$ & Std. Error & & & \\
\hline (Constant) & 30.042 & .933 & \multirow{3}{*}{-.651} & 32.207 & .000 \\
\hline \multirow{2}{*}{$\begin{array}{l}\text { PR Total } \\
\text { (Constant) }\end{array}$} & -.334 & .039 & & -8.480 & .000 \\
\hline & 18.314 & 3.075 & & 5.956 & .000 \\
\hline \multirow{2}{*}{$\begin{array}{l}\text { PR Total } \\
\text { Trust Total }\end{array}$} & -.241 & .044 & -.469 & -5.534 & .000 \\
\hline & .404 & .102 & .337 & 3.977 & .000 \\
\hline
\end{tabular}

a. Dependent Variable: Customer Adoption Total

The co efficient table explains that, the variable significantly influence the dependent variable. The table shows that the factors perceived risk (sig. $0.000<0.05$ ) and trust (sig. $0.000<0.05$ ) have significant relationship with customer adoption. Therefore, the validated model is as follows;

\section{$\mathrm{Y}($ Customer Adoption $)=18.314-0.469($ perceived risk $)+0.337$ (trust)}

Therefore, in sum, perceived risk negatively influences customer adoption of internet banking and trust positively influence customer adoption. It indicates that, $100 \%$ increase in perceived risk leads to $46.9 \%$ decrease in customer adoption of internet banking. At the same time, 100\% increase in trust leads to $33.7 \%$ increase in customer adoption of internet banking.

\section{Findings}

The study analyse the various factors that influence the adoption of internet banking between male and female respondents because the behaviour and attitude of male towards new technologies are different from that of 
female. So, the analysis of various dimensions such as perceived usefulness, ease of use, behavioural control, and attitude, risk and trust across male and female are analysed.

The findings are highlighted as follows;

- With regard to usefulness, mean and standard deviation of male are 27.77 and 2.64 compared to 28.56 and 1.88 in case of female. Therefore, there is significant difference with regard to usefulness between male and female. It indicates that, female respondents are mostly satisfied with usefulness factor as compared to male.

- In the case of easiness factor, mean and standard deviation of male are 21.85 and 2.96 compared to 22.43 and 2.12 in case of female. There is significant difference with regard to easiness between male and female. It indicates that female respondents are mostly satisfied with easiness factor as compared to male.

- The study reveals that, in the case of perceived behavioural control, mean and standard deviation of male are 17.37 and 2.12 compared to 18.06 and 1.83 in case of female. Therefore, there is no significant difference with regard to perceived behavioural control between male and female.

- With regard to attitude, mean and standard deviation of male are 24.92 and 2.53 compared to 25.84 and 3.16 in case of female. There is significant difference with regard to attitude between male and female. It indicates that, female respondents are agreed with attitude factor mostly as compared to male.

- With regard to trust, mean and standard deviation of male are 23.22 and 2.79 compared to 4.47 and 3.25 in case of female. There is no significant difference with regard to trust between male and female.

- Considering perceived risk, mean and standard deviation of male are 23.64 and 6.05 compared to 21.32 and 8.17 in case of female. There is significant difference with regard to perceived risk between male and female. It was found that, male respondents perceive high risk as compared to female.

- Comparative analysis of customer adoption between male and female based on mean and standard deviation shows that, female have highest mean (22.52) than male (22.48). The result shows that, the significance value .202 is more than $0.05(.202>0.05)$. Therefore, there is no significant difference between customer adoption among male and female.

- The analysis of interrelationship between customer adoption and various factors of adoption reveals that, perceived risk and trust have high correlation between customer adoption and trust has positive correlation (.589) with customer adoption.

- The first model of perceived risk gives an $\mathrm{R}$ square value of 0.423 which states that, $42 \%$ of the variation in customer adoption is predicted by perceived risk alone. In the second model, the $\mathrm{R}$ square value is improved to 0.504 , which states that perceived risk and trust together explains $50 \%$ variation in customer adoption. Both the models are statistically significant at $5 \%$ level of significance $(\operatorname{sig}(0.000)<0.05)$.

- Analysis of the influence of perceived risk and trust reveals that, the factors perceived risk (sig. $0.000<$ 0.05 ) and trust (sig. $0.000<0.05$ ) have significant relationship with customer adoption. The validated model is, $\mathrm{Y}$ (Customer Adoption) $=18.314-0.469$ (perceived risk) +0.337 (trust). This result indicates that $100 \%$ increase in perceived risk leads to $46.9 \%$ decrease in customer adoption of internet banking. Similarly, $100 \%$ increase in trust leads to $33.7 \%$ increase in customer adoption of internet banking. Therefore, it is stated that Perceived risk negatively influence customer adoption of internet banking and trust positively influence customer adoption.

\section{Suggestions}

Based on the findings, the following suggestions are put forward;

- Banks must initiate proactive measures to increase the awareness of customers regarding the innovative services by conducting training programmes, awareness programmes, and demonstrations at the counter and personnel interactions.

- The banks must instil confidence among customers by creating trust. The customers have fear of loss of money and personal information while using internet banking. So, the banks must allay this fear by informing them about the security and privacy measures. 
- Banks must insist to take all the precautions for the safe use of internet banking like VeriSign, Virtual Keyboard, One time password etc.

- In many cases, the customers face problems with internet banking website. Therefore, the banks must remove such barriers and resolve all the issues associated with internet banking.

\section{Conclusion}

This study on the topic "A Study on Factors Influencing the Adoption of Internet Banking - A Gender wise analysis by Integrating TAM and TPB Model in Kerala" is conducted to identify the influence of adoption factors on internet banking usage and the gender disparity in customer adoption of internet banking. The study found that, perceived risk and trust are the important factors that influence the adoption of internet banking. A lot of efforts are needed to improve the quality of internet banking services. The female customers are mostly satisfied with usefulness, easiness and attitude as compared to male. The risk factor is high in case of male as compared to females. The main problem is the fear of customers regarding the security of using internet banking. By giving proper training and awareness to the customers, the banks can instill confidence among them and by creating trust they can retain customers. So, dream behind replacement of branch banking to online banking can be achieved.

\section{References}

Techniques, Yamuna Publications, Thiruvananthapuram. Maheshwari, S.N, Paul.R.R, Banking Theory and Practices, Kalyani Publications, Ludhiana.

Kamakodi,N.(2007), Customer Preference on e-Banking Services, Banknet Publications,Vol.IV

Habbar,R. (2004), Building Trust in e- Banking, Vinimaya,Vol.XXIV

Gupta.Shashi K, Rangi. Praneet, Reasearch Methodology (2nd ed.), Ludhiyana, Kalyani Publications, 2013.

Potti. L.R, Quantitative

Raju, V P. "Influence of Technology in Banking - A Customer Centric Study with Special Reference to Kerala", Mahathma Gandhi University,Kerala, 2015 (112-159)

George, Ajimon. G.S, Gireesh Kumar“ A Customer Centric Study on Internet Banking in Kerala”, Mahathma Gandhi University, Kerala ,2013 (82-95)

Ming-Chi, L. (2009). Factors influencing the adoption of internet banking: An integration of TAM and TPB with perceived risk and perceived benefit, Electronic Commerce Research and Applications, 18, 130-141.

Long Li (2011). A Critical Review of Technology Acceptance Literature. Department of Accounting, Economics and Information Systems, (2-14)

Mohamed Gamal, Aboelmaged. Tarek R, Gebba (2013). Mobile Banking Adoption: An Examination of Technology Acceptance Model and Theory of planned Behavior. International Journal of Business Research and Development ,ISSN 1929-0977 | Vol. 2 No. 1, pp. 35-50

Rahmath Safeena, et al. (2013)“Combination of TAM and TPB in Internet Banking Adoption" International Journal of Computer Theory and Engineering, Vol. 5, No. 1, (146-150)

Sara Naimi Baraghani (2008) "Factors Influencing The Adoption of Internet Banking”, (20-65)

Chih-Chung Chen (2013) his study titled "The exploration on network behaviors by using the models of Theory of planned behaviors (TPB), Technology acceptance model (TAM) and C-TAM-TPB”, African Journal of Business.78-86

Ajzen, I. (1991). The Theory of Planned Behaviour. Organisation Behaviour and Human Decision Processes, 50 (2), $179-211$.

Ajzen I. Perceived behavioral control, self-efficacy, locus of control, and the theory of planned behavior1. 2002. p. 66583. 